\title{
Foreign Direct Investment and Social Sectors Development: A Review
}

Sadia Idrees' ${ }^{1}$, Nor' Aznin Abu Bakar ${ }^{2}$

${ }^{1} \mathrm{PhD}$ Scholar, School of Economics, Finance and Banking (SEFB), College of Business (COB), Universiti Utara Malaysia.

${ }^{2}$ Associate Professor, School of Economics, Finance and Banking (SEFB), College of Business (COB), Universiti Utara Malaysia.

Email: midrees@gmail.com

\begin{abstract}
Various studies in the past have examined the effect of foreign direct investment on economic growth, the key basic assumption common to these papers is that economic growth is a good proxy for welfare of both developed and developing countries. However, research on the influence of foreign direct investment on an expanded conception of socio-economic progress such as human development (measured by the human development index) is absent. This research paper presents the literature on foreign direct investment (FDI) and social sectors (health \& education) development in the context of developing economies.
\end{abstract}

Keywords: $\quad$ Foreign Direct Investment, Health, Education, Pakistan

\section{Introduction}

Education and health are considered as the key social sectors that not only contribute in the development of the country and social growth but also contribute to enhance the social welfare of the people. By the recent development of the empirical and theoretical research on the social sciences, that social sectors contribution toward the economic growth of the country, although development of human capital, the conditions of education, and health of the population are the key factors to measure the economic growth of the country (Bakar, Hasseb\&Azam, 2014; Romer, 1986; Lucas, 1988).

Notwithstanding there are many factors, that affect educational development and population health, one of the key focus of this study is the role of inward FDI in promoting the social sectors. The concept of Foreign Direct Investment (FDI) explains as the investment money which comes from the international sources in the domestic region of a country. To study the impact of FDI on the health and educational development, it is very much significant to divide it into the direct and indirect component. But the significant point of discussion is the direct impact of FDI through some qualitative measures (welfare gains from 
FDI). These are in the form of social sectors (health \& education) development. For instance, the level of foreign investment can make a direct contribution by providing the job opportunity in the local market, income enhancement while its indirect impact is not very much visible (Asghar, Azim, \& ur Rehman, 2011).

The indirect benefits of FDI to the local economy or host economy it promotes the economic development through spillover effect, and finally the demonstration effect. FDI has a very significant role for the development and economic growth in the country as it boosts the investment and job opportunities in the local market and finally increase the standard of living (Basu \& Ghosh, 2017; Javorcik, 2014). In addition, the significant advantages of FDI can be in the form of knowledge transfer, capital shifting and increase in the value of the balance of payment for the economy (Baliamoune-Lutz, 2004; Branstetter, 2006; Perri \& Peruffo, 2016). Various studies have considered FDI as a key indicator for the growth of the domestic economy in different regions both developed and developing states (Alfaro, Chanda, Kalemli-Ozcan, \& Sayek, 2004; Balasubramanyam, Salisu, \& Sapsford, 1996; Bengoa \& Sanchez-Robles, 2003; Carkovic \& Levine, 2005).

In the past, number of studies emphasized that welfare and the growth of economy have the positive correlation and GDP growth take as the proxy to measure the social welfare. But recently, this assumption has been confronted by the argument that evident by the number of sources, recent studies claim that GDP can be growing while poverty condition are on rice.

To bridge this gap, a limited number of investigations have been done on the relationship of FDI and welfare. Therefore, this study might be an attempt to present an idea by investigating the health and educational development through Foreign Direct Investment.

\section{Social Sectors (health \& education) development and welfare gains from Foreign Direct Investment: A Review}

Past studies that have been conducted on the effects of FDI have been mostly particular focus on the exclusive benefits that might a local economy take for the growth of host country economy in terms of wages and growth. However the past literature lacking to investigate the FDI effects toward important dimensions such as living quality in terms of education and health conditions among the range of neglected topics (Blonigen and O'Fallon 2014). Although the literature is available and investigations are done on the causal behavior of FDI and economic growth such as, (Alfaro, Chanda, Kalemli-Ozcan, \&Sayek, 2004; Alfaro, Chanda, Kalemli-Ozcan, \&Sayek, 2010; Haseeb, Hartani,_Bakar, Azam\& Hassan (2014); Carkovic\& Levine, 2005; Chowdhury and Mavrotas; Hansen \& Rand, 2006), 
whereas, the studies on the relationship between social sector development and FDI are limited.

Past literature is emphasized that health is the one of the factor that leads development as mentioned by the united nations (United Nations, 1980), but unfortunately that part of development is largely ignored in the past decades and limited literature available on the effects of FDI. As Blonigen and Wang, (2005) argued that population health improves by the health, sanitation, and clean water, quality education, and health facilities, that may cause the FDI, because if it increases ultimately, income increase that leads toward expenditures that made on goods such as education and health. The effects of FDI toward growth in developing nations are more stronger than the developed countries. Additionally, if health care activities need to spend extra expenditure from the personal income, might the cause in increase in diminishing personal income, that means health gain effect the living standards particularly in poor countries,

On the other hand, in the rich or the high income economies, effect is inversed, for instance, such as If higher income depends on the long working schedule that may cause the less sleep, less social interactions, and stressful routine, also the it increase the consumption of unhealthy food such as, burgers and fries and hnhelathy products as well, such as alcohol and tobacco, that might have the negative relationship between health and income. (Preston, 1975). Besides that minimal people spend money on the helath care actinites and on helath food such as on fish meat and vegetables while an increase in income, in is not conditional that health functions are always negatively corelated (Herzer and Nunnenkamp, 2014).

As Bitzer \&Kerekes, 2008; and Ang and Madsen, 2013 postulated that "health care is reasonably a superior good." In line with the past discussion on the basis of vital evidences that came from the developed countries, total factor production is considered as the significant factor that brings knowledge through FDI inflow in the host country (Bitzer \&Kerekes, 2008; Ang and Madsen, 2013). Similarly, in this sense, the spillover of international knowledge brings medical knowledge in healthcare sector while FDI inflows increasing toward host country in the sector of heath, that ultimately improve the quality of health outcomes. Correspondingly, FDI will further improves environmental and living standards of people which are driven by the technological advancements, and ultimately generate an alleged pollution halo effect, that is, actually environmental friendly advancement of technology that are transferred along with the FDI inflows (Zarsky, 1999). This view of 
FDI assumes that FDI came from the developed countries is the important to improve domestic production of the firm.

The effects of FDI more focused in the past are the indirectly, but it might assume that there are more direct effects of FDI that might improve the health outcomes. For instance, health outcomes can improve by the FDI while FDI invested directly toward the horizontal toward market seeking opportunities such as in the health sector by making the low price than existing medical services and the goods (e.g., medical equipment) as well. However FDI can contribute positively toward health by promoting the health products than the negative contribution by producing the health damaging goods or services likewise, fast food, tobacco, and alcohol

It is also evident that FDI also improve the motivation toward growth of an economy, improve the working environment and conditions by the help of advanced technology, and contribute to increase wages (personal income) in the developing and under developed countries (Feenstra \& Hanson, 1997a, 1997b; Lai \& Sarkar, 2017; Moran, 2005; Xu \& Sylwester, 2016). That factor might have direct effect on the healthcare situations of the country, particularly in developing and under developed counties because low income countries health care conditions are more dependent on the purchasing power of the individuals. However, if the foreign firms are not paying significant amount to their employees in terms of wages in the host county, then it is significantly important to study the host country's domestic firms, because in this situation, domestic firms have more capability to facilitate their employees in terms of health care and social and benefits.

On theoretical ground it is proven that there is positive relationship between GDP per capita and both FDI and trade openness, it is also beneficial for improvement life expectancy because high wages enables people to afford high quality nutritious foods, high quality living standards, quality treatment of health, and enable to invest quality working conditions and living that expressively improve expectancy of life (Borensztein et al. 1998). Additionally, FDI and openness of trade are the resources of technology dissemination, while, in the developing countries health of the people can be enhanced by the increasing trend to access toward new technologies for the better health such as, advance medical treatment, water sanitation, and medications. (Xu and Wang 2000; Ciruelos and Wang 2005).

A study conducted by Owen and Wu (2007) using data of 219 countries over the globe, on the effect of trade that have on the health outcomes. The empirical study revealed that increasing trend of trade openness have the relationship to lower the rates of infant 
mortality in the developing countries and also have the positive link with higher life expectancy.

Another study that have been examined by Hawkes (2005) on the highly processed foods. Investigated the relationship among nutrition transition and role of FDI. Sample taken from the transnational food companies (TFCs) working in developed economies, the results of this study revealed that there is a significant role FDI plays in nutrition transition to enable and promote the uses of foods that containing nutrition's in low income countries.

There is a significant body of literature that revealed the relationship between FDI and unhealthy food consumption (such as tobacco and alcohol), over consumption of nutrition, and increasing level of damaging pollution, and, explains that all factors have direct effect on the health of population (Hawkes, 2005; Jorgenson 2009, 2009a). Similarly, another study, conducted by Jorgenson $(2009,2009$ a) also examine the FDI in secondary sector industry, using panel data analysis of 3035 developing countries and water pollution levels. The findings of the study revealed that secondary sector FDI have a relationship toward elevate pollution, that ultimately increases child, and infant mortality as well.

In the past literature it is evident that a positive and strong relationship exists between human capital and FDI in terms of the level of schooling. A study results revealed that the local skills availability, has become a related factor that attract FDI in the globalization process started from the 1990s (Nunnenkamp,2002). In addition, accumulated human capital measured in terms of enrollment in primary school also positively corelated with FDI. On the other hand, some authors suggested that in the developing economies, tertiary education level not significantly dependent on FDI inflows. But in Asian countries, it is empirically and statistically proved that FDI has a significant positive impact on the enrolment of school at the tertiary and primary levels (Gittens, 2006). While, the number of researchers such as $\mathrm{Xu}$ (2000) and Borensztein, De Gregorio, and Lee (1998) argued that although technology transfer promoted by FDI, but in the host country's production improvement highly depend on the achievement of minimal level of education.

Furthermore, to support above arguments, Hanushek (2013) also stressed that the expansion of schooling system is one of the significant part of any country's development plans and also for the international organizations. The author further argued that in the context of developing world, the economic growth will remain unable to improve unless they have the quality schooling system. Blomstrom and Kokko (2002) found that in Latin US regions and in East Asian countries for the development of human capital, FDI inflow can produce an 
advantageous environment. because host country's employees training in both regions' will enhance their education level, due to the FDI inflows, and that employees will adopt more advanced technology in the process of production.

Another study conducted by Lehnert, Benmamoun and Zhao (2013) anchored with175 countries panel data analysis and explores that the country nationalgovernance mediate the relationship between FDI and the knowledge and welfare infrastructure of local countries. The results also explore that FDI have a positive relationship with host country's economy, and further found that FDI also helps to enhance overall welfare of the country in terms of health, education, and living standard of people. The analysis of the above discussed study also support the argument FDI supports household and also the governments of host country in terms of additional resources and funds to improve living standards, health and education. But surprisingly that study revealed that the technological innovation has a negatively linked with FDI. The results of above mentioned study can be theoretically true while investigating the mediating role of governance (Meyer, 2004). Because the reason behind that developing countries apply that spillover possessions for the development of transportation, to overcome energy crises, and communication tools, by creating the technological structure.

Reiter and Steensma (2010) further explains the linkage between social sectors development of FDI such as education and health by using the 49 developing countries getting data from Human Development Index of UNDP (2007/2008) for the time period of 1980-2005. To investigate the influence of corruption and country's policy on FDI on these relationships. And interestigly revealed that FDI have strong positive relationship human development during the restriction of foreign investor entry in some economic segments and also in the condition when discrimination isexisting against foreign investment comparatively local investment. The FDI and improvement of human development also positively associated during low corruption levels

Burns et.al (2017) further investigated the linkages between population health and FDI by using 85 LMICs panel data of 1974 to 2012. The study revealed that in terms of life expectancy FDI have positive effect on overall people's health, FDI also found positively correlated toward overall health during investigation of specific age mortality. Particularly positive effect on the adult mortality, surprisingly no relationship found with child or infant mortality. In conclusion, the effects of FDI on the health are remain still unclear in almost all models that are investigated in past. However the investigation of sector-specific FDI toward 
the health in LMICs, might be an attempt provided clear evidence of a low negative relationship between overall life expectancy and manufacturing sector FDI.

Shaikh, F (2007) used the CGE framework to analyze the effect of foreign direct investment on poverty alleviation in the context of Pakistan. The results indicated a significant role of FDI in reducing urban poverty whereas showing insignificant impact on rural household poverty. In recent times during 1992 to 2007 a large amount of FDI brought in Pakistan while in Asia the poverty has been linked directly or indirectly with the development initiatives. In the last couple of decades, the issue of poverty has become prominent. The development literature refers to two types of poverty one is the absolute poverty and the other is the relative poverty. Only in 2006-07 the total FDI was 2,096 million. It has affected the urban population in general. However, the government poor policies reduced the benefit of rural households from the FDI investment.

Mughal and Vechu (2009) examined the components of secondary and tertiary education covering the period of 1999-2006. The results revealed that the FDI has a weak but a negative significant effect on both secondary and tertiary education. The study endorsed the theoretical proposition explaining education is positively affected by country's growth rate. The results revealed a positive impact of per capita Gross National Income (GNI) on both low and middle-income countries. However, the impact is not same for the two group of countries. The differences identified such as role of agriculture and growth in population.

However, Olaf and Groot (2014) also investigated the link between economic growth and FDI by adding two variations. First, a comparison was made between the two panel estimation models; fixed effect model and Generalized Methods of Moments. Secondly, three more variables; Human Development Index, household consumption and inequality were added. The results indicated insignificant impact of FDI on economic and household consumption growth while it has significant positive effect on inequality and negative impact on human development index. These results were unprecedented.Kheng, Sun and Anwar (2017) explored the relationship between human capital and foreign direct investment considering 55 developing countries for the period 1980 to 2011. The results based on simultaneous equation fixed effect model suggested bidirectional causal relationship. It has suggested the importance of human development in case of China and Brazil.

Sharma and Gani (2014) investigated that both in developed as well as in developing countries, the economic development is directly affected by the foreign direct investment (FDI) on the countries' economy. Though, limited research is done on the effect of FDI on the 
basic factors of social and economic growth like health sector and education sector. In current article, the influence of foreign direct investment (FDI) is examined on the development of societal sectors (evaluated on the basis of human progress index) for medium and povertystricken nations from the year 1975 till 1999 to bridge this gap. The results of regression analysis of the fixed effect model has demonstrated the direct and positive influence of FDI on the development of social regions of both country groups.

Herzer and Nagel (2015) studied the influence of FDI on the health of population with utilizing panel data from nearly 179 nations from year 1980 till year 2011. The basic outcome indicated that there is association between foreign direct investment and healthiness; with nonlinear effect which depends upon the income level. Foreign direct investment is positively related with health at low income levels, but this effect is reduced when income is increased, then the sign alters and show gradually more negative results at higher income levels.

Azamet,al. (2015) analyzed the impact of foreign direct investment on Human Capital. Human capital which is evaluated by the schoolingyear level of thirty four developing nations from the timeperiod range of 1981 to 2013 depends upon theHausman test, Fixed effects (FE) model. The research has detected the influence of the household level of income; the higher workers' remittances inflows of the countries, exports and foreign direct investment has positive relationship with human capital. Thus, it is concluded that foreign direct investment inflows has a constructive part to increase enrollment of school and thereby stimulating human capital. As a result, the social wellbeing of the individuals of developing nations willbe improved. The achievement of high level of income iscritically significant for the developing countries as it is important to improve enrollments of schools andeventually encouraging human capital.

Ndeffo (2010) has presented the research to find the influence of FDI on the growth and progress of human capital with the use of panel data approach in almost thirty-two countries of Sub-Saharan Africa from the year 1980 to 2005. Human capital is measured on the basis of kid's percentage in permanent education systems of primary and secondary schooling. The outcomes of the study were not significant demonstrating that foreign direct investment engaged for Sub Saharan African countries is yet deficient. Therefore, extraordinary efforts are needed to improve the attraction of foreign direct investment in this division of the Africa. There are few other constructs having directly significant as well as positive influence on children's percentage in permanent education system. They are the rate 
of domestic investment, public segment expenses, life probability at birth and the progress of GDP rate according to per capita.

Gittens and Pilgrim (2013) examined the impact of FDI on the Human Capital increase, they employed a dynamic panel procedure utilizing the data be an average of nearly the period of 5 years; 1970 to 2010, in which the Human Capital was studies as the basic variable along with various variables of macro-economic factors. It is assumed that advancement in technology are affected by the inflow of cash through foreign direct investment that influences mega economic variations further stimulating the accumulation of Human Capital. This present research paper established that foreign direct investment is positively related to the variables of human capital symbolized by primary-secondary school average times, accomplishment of education of all population, and the higher education percentage of all population during almost 15 years of era. But, this progressive influence was not significant on the statistical basis if the descriptive variables were expanded in every item. Moreover, though education enhancement and technological concentration are recognized as sources of development; the proofs recommended that the association of education of tertiary level and foreign direct investment resulted insignificant in case of developing nations.

Alam (2015) explored that high associations are found among the openness of business, FDI and expectancy of life in context of Pakistan from year 1972 to year 2013. The mutual co-integrated method of Bayer and Hanck (2013) helped to study the equilibrium association in long run between these variables. Additionally, they used the autoregressive distributed lag (ARDL) method to evaluate the long-term and short-term influence towards the life expectancy of foreign direct investment and openness of trade. It is confirmed from past empirical studies that trade openness improves health outcomes of population evaluated on the basis of life expectancy. Foreign direct investment positively influences the life expectancy. The relationship of foreign direct investment and trade openness towards life expectancy is unidirectional. The main outcomes recommended that foreign direct investment and trade openness has significant contribution to life expectancy in Pakistan.

Gohou and Soumare (2012) re-examined the association among the inflows of FDI and social wellbeing in countries like Africa by applying per-capita net entries of foreign direct investment and the human development index of UN Program as primary variables. The results of analyses established a significant and positive relation between poverty reduction and cash inflows of foreign direct investment in Africa, however they determined substantial variances between different regions of African. They also determined that the 
influence of foreign direct investment is larger in poorer nations in comparison with the richer nations. For example, the relationship of poverty reduction and foreign direct investment is substantial and positively influential in countries like East and central Africa, but this relationship is insignificant in Southern and Northern regions of Africa. In addition to these regions, in West Africa, this association is detected to be vague.

According to Gaston \&Gohou (2009), it has been assessed that in regions of Africa, there is clear influence of FDI on societal well-being. In past literature, there exist a causal relationship of economic growth and foreign direct investment as it is established that the economic development is best representation of society welfare. Though, some of these research papers are dedicated to Africa related to its local discrepancies to attract foreign direct investment. So, the index of human development and actual per capita Gross Domestic Product is used to evaluate prosperity and society well-being measure. To measure foreign direct investment, they applied independent measures of the net inflows of per capita foreign direct investment, net inflows of foreign direct investment over gross capital formation, and net inflows of foreign direct investment over Gross domestic product. The results established a positive, significant association of society wellbeing and foreign direct investment at the cumulative level in Africa, and this strong relation remains consistent even later the control of government size, political threats, expansion of infrastructure, obligation, trade openness, macro-economic uncertainty, quality of institutions, education progress and improvement of fiscal markets. Though, on the local level basis, the relationship of foreign direct investment and well-being is not clearly observed and fluctuates crosswise regions.

Hung (2005) determined empirical researches to detect the influence of foreign direct investment poverty reductions in direct as well as indirect methods by using the panel data analysis in surveyed provinces and cities in Vietnam from the era of 1993-2002. The principal results originated from the research show that at provincial level, foreign direct investment inflows and economic growth expresses a positive and significant influence on reduction of poverty. Due to this significant association of foreign direct investment inflows and economic growth with reduction of poverty in different regions, this fact is revealed that labor-accelerated trades might decrease poverty quickly. Therefore, in labor-intensive businesses the management must boost inflows of foreign direct investment. The rules and guidelines must comprise of tax incentive provision, training of individuals particularly at regional level where the population is not well educated. 
Pakistan Journal of Humanities and Social Sciences, 7(1), 2019

Spinova and Ougate (2017) explored the effect of FDI on GDP per capita and relationship between FDI and social development for European developing and transitional countries for years 1995 to 2016 by using panel data. They found a positive link of gross domestic product and foreign direct investment. The relationship between FDI and socialdevelopment is not significant. Their results deviate from some of the previous literatures because of the difference in the level of development of the countries. Results from less developed countries like SUB Saharan Africa and Latin America and Caribbean and most of Asian countries showed that significant effect of FDI on life expectancy and income distribution. But some of the results of FDI for developed countries are not significant for income distribution and life expectancy which is similar to their results. The deviation of results may depend on the fact that most European developing country's FDI/GDP ratio is lower due higher GDP per capita than in less developed countries. Depending on this fact the effect of FDI on income distribution and life expectancy will be less or insignificant. They recommend a further study on this subject in the future because of time limitation FDI might become significant in the long run.

\section{Conclusion}

It has been concluding that generally, foreign direct investment (FDI) has a significant impact on the society well-being of host country. It is evident that foreign direct investment was positively influence the host country's economy, and thus it supports the global well-being, evaluated on basis of living standard, education quality and health. Empirical findings of research have been supported the assumption that foreign direct investment improve surplus reserves and wealth of the government of host country and household necessities to improve welfare likewise the health care sector, standardized living and quality education. Therefore, this study emphasizes that foreign direct investment shows extraordinary surplus influences than development of technology in developing countries only, while, also enhances ecological and societal progress. As for as possible, the straight and indirect impacts of foreign direct investment on social welfare discussed, the amount of FDI is more beneficial than its spillover effects when it direct comes into the health and education sector. 


\section{References}

Alam, M. S., Raza, S. A., Shahbaz, M., \& Abbas, Q. (2016). Accounting for contribution of trade openness and foreign direct investment in life expectancy: The long-run and short-run analysis in Pakistan. Social Indicators Research, 129(3), 1155-1170.

Alfaro, L., Chanda, A., Kalemli-Ozcan, S., \& Sayek, S. (2004). FDI and economic growth: the role of local financial markets. Journal of international economics, 64(1), 89-112.

Ang, J. B., \& Madsen, J. B. (2013). International R\&D spillovers and productivity trends in the Asian miracle economies. Economic Inquiry, 51(2), 1523-1541.

Asghar, N., Azim, P., \& ur Rehman, H. (2011). Impact of government spending in social sectors on economic growth: A case study of Pakistan. Journal of Business \& Economics, 3(2), 214.

Balasubramanyam, V. N., Salisu, M., \& Sapsford, D. (1996). Foreign direct investment and growth in EP and IS countries. The economic journal, 92-105.

Baliamoune-Lutz, M. N. (2004). Does FDI contribute to economic growth? Knowledge about the effects of FDI improves negotiating positions and reduces risk for firms investing in developing countries. Business Economics, 39(2), 49-57.

Basu, S., \& Ghosh, S. (2017). FDI in India: Understanding the Implications for Growth and Job Creation. Journal of Management and Public Policy, 9(1), 5-16.

Bengoa, M., \& Sanchez-Robles, B. (2003). Foreign direct investment, economic freedom and growth: new evidence from Latin America. European journal of political economy, 19(3), 529-545.

Bitzer, J., \& Kerekes, M. (2008). Does foreign direct investment transfer technology across borders? New evidence. Economics Letters, 100(3), 355-358.

Branstetter, L. (2006). Is foreign direct investment a channel of knowledge spillovers? Evidence from Japan's FDI in the United States. Journal of International economics, 68(2), 325-344.

Carkovic, M., \& Levine, R. (2005). Does foreign direct investment accelerate economic growth? Does foreign direct investment promote development, 195.

De Groot, O. (2014). Foreign direct investment and welfare.

Feenstra, R. C., \& Hanson, G. H. (1997a). Foreign direct investment and relative wages: Evidence from Mexico's maquiladoras. Journal of international economics, 42(3-4), 371-393.

Feenstra, R. C., \& Hanson, G. H. (1997b). Productivity Measurement and the Impact of Trade and Technology on Wages: Estimates for the US, 1972-1990: National Bureau of Economic Research.

Gohou, G., \& Soumaré, I. (2009). Impact of FDI on poverty reduction in Africa: Are there regional differences. Paper presented at the African Economic Conference.

Hanushek, E. A. (2013). Economic growth in developing countries: The role of human capital. Economics of Education Review, 37, 204-212.

Haseeb, M., Hartani, N. H., Bakar, A., Azam, M., \& Hassan, S. (2014). Exports, foreign direct investment and economic growth: Empirical evidence from Malaysia (19712013). American Journal of Applied Sciences, 11(6), 1010-1015.

Hawkes, C. (2005). The role of foreign direct investment in the nutrition transition. Public health nutrition, 8(4), 357-365.

Javorcik, B. S. (2014). Does FDI bring good jobs to host countries? The World Bank Research Observer, 30(1), 74-94.

Lai, Y.-C., \& Sarkar, S. (2017). Do high FDI Indian firms pay low wages \& have higher output? Indian Journal of Industrial Relations, 52(3), 432-443. 
Moran, T. H. (2005). How does FDI affect host country development? Using industry case studies to make reliable generalizations. Does foreign direct investment promote development, 281-313.

Mughal, M., \& Vechiu, N. (2009). Does FDI promote higher education? Evidence from developing countries. Paper presented at the 10th Nordic Conference in Development Economics (NCDE).

Muhamad Shaikh, F. (2007). Impact of foreign direct investment on poverty alleviation in Pakistan by using CGE model.

Perri, A., \& Peruffo, E. (2016). Knowledge spillovers from FDI: a critical review from the international business perspective. International Journal of Management Reviews, 18(1), 3-27.

Sharma, B., \& Gani, A. The effects of foreign direct investment on human development. Global Economy Journal, 4(2).

Tahir, M., Khan, I., \& Shah, A. M. (2015). Foreign remittances, foreign direct investment, foreign imports and economic growth in Pakistan: a time series analysis. Arab Economic and Business Journal, 10(2), 82-89.

Xu, X., \& Sylwester, K. (2016). The effects of foreign direct investment on emigration: The roles of FDI source country, education, and gender. Economic Modelling, 55, 401409.

Zarsky, L. (1999). Havens, halos and spaghetti: untangling the evidence about foreign direct investment and the environment. Foreign direct Investment and the Environment, 13(8), 47-74. 